\author{
K.A. Zhumasheva ${ }^{1}$, G.P. Pogossyan ${ }^{1}$, B.K. Zhumashev ${ }^{2}$, M. Danilenko ${ }^{3}$ \\ ${ }^{I}$ Ye.A. Buketov Karaganda State University, Kazakhstan; \\ ${ }^{2}$ L.N. Gumilyov Eurasian National University, Nur-Sultan, Kazkhstan; \\ ${ }^{3}$ Ben Gurion University of Beersheba, Israel \\ (E-mail: zkkbg@mail.ru)
}

\title{
Genetic condition of human papillomavirus high carcinogenic risk
}

\begin{abstract}
The authors consider the basic concepts of HPV-induced carcinogenesis and the molecular differences found among types of HPV and intra-type variants, and give their clinical and functional consequences. Human papillomavirus (HPV) is a diverse group of small DNA viruses, some of which have been extensively studied over the past three decades due to their carcinogenic potential. The persistence of viral infections and the uncontrolled expression of the E6 and E7 viral oncogenes are critical events in the transformation process. It is important to note that viral types are specific for each type of cell and usually cause various types of lesions, benign or malignant. Recognizing the critical role that certain specific types of HPV play in the development of cervical cancer is very important for their prevention and public health strategies for cervical cancer, which are still the leading cause of death among cancer patients in many countries.
\end{abstract}

Keywords: human papillomavirus, cervical cancer, keratinocytes, oncogenesis, malignant transformation, virion, capsid, viral oncogenes E6 and E7, regulatory cell proteins $\mathrm{p} 53$ and $\mathrm{pRb}$, minor proteins L1 and L2, long control region of human papilloma virus (LCR HPV), line of immortal HeLa cells.

The widespread prevalence of oncological diseases, their medical, social and economic significance, make the problem of studying the mechanisms of oncogenesis, prevention, early diagnosis and treatment of malignant tumors one of the key in modern healthcare. Genetic studies on cancer, which have occupied and occupy one of the leading places in experimental oncology, have made a significant contribution to a more complete understanding of the mechanisms of carcinogenesis. The genetics of cancer makes us reconsider simple dogmas about a causal relationship in diseases.

In recent years, the sharp growth rate of neoplastic neoplasms in the organs of the reproductive sphere of the female population has become especially important. During the first year of diagnosis, every eighth woman dies in breast cancer (BC), every fifth woman dies in cervical cancer (CC), and every second to third in ovarian cancer (RJ). Most of these women are between 30 and 55 years old. Studies have established that one of the important factors in the high mortality among women from gynecological oncology is the late diagnosis of malignant necrosis, and most of the identified patients have a 3rd or 4th stage of tumor development. In connection with the large reproductive losses from malignant necrosis, the problem of oncopathology goes beyond the scope of medical tasks and is of an important medical, social and state significance [1].

Nowadays, diseases associated with the human papillomavirus (HPV) have attracted the attention of various specialties, including obstetrician-gynecologists and pediatricians. Today, HPV infection is one of the most common sexually transmitted infections (STIs), which infected most of the sexually active population of the planet. The peak of HPV infection occurs at a young age from 15 to 30 years, according to various authors is from 17.6 to $20.8 \%$ among women in this age group [2]. After 30 years, the frequency of HPV infection ranges from 8.6 to $9.9 \%$, while the detection of dysplasia and cervical cancer increases significantly [1].

One of the most important achievements in the field of cancer research is the establishment of the etiological role of some types of human papillomavirus (HPV) in the development of cervical cancer (CC) [1]. Currently, more than 80 types of HPV have been characterized and it has been shown that about 40 types can cause diseases of the anogenital tract [2]. Based on epidemiological and molecular biological studies, the types of HPV that infect the mucous membranes of the anogenital tract are divided into low and high oncogenic risk groups [3]. The most common types of HPV high oncogenic risk are 16 and 18 types - they are found in $60-80 \%$ of all cases of cervical cancer [4].

About 35 types of HPV cause damage to the integumentary epithelium of the mucous membranes of the genitals and approximately $99.7 \%$ of all squamous cervical cancers of the cervix contain HPV DNA [1-5]. HPV is one of the main etiological agents of both genital and non-genital carcinogenesis. More than 600,000 
cases of cancer associated with human papillomavirus are detected worldwide annually, representing $12 \%$ of all cancer cases reported in women [1-10].

The human papillomavirus is one of the most common viruses, belongs to the genus papillomavirus (Papillomavirus) and belongs to subgroup A of the family Papovaviridae. This group of viruses is very diverse, and many of its representatives do not cause any symptoms. More than a hundred types of HPV have been identified, of which 35 are capable of infecting the human urogenital tract, causing damage to the integumentary epithelium of the skin and mucous membranes of the genital organs. HPV affects the cells of the skin and mucous membranes - keratinocytes, which serve as the main mechanical barrier between the external environment and the internal environment of the body, causing the proliferation of epithelial cells in the form of warts, less often in the form of extensive formations (condyloms). HPV can be found on the skin, oral mucosa, conjunctiva, esophagus, bronchi, and bladder. HPV is a highly contagious virus with an incubation period of 34 weeks to 8 months, (average 3 months) [11-15].

The role of HPV 16 in the development of cervical cancer was first described by German scientist Harald zur Hausen, in 1983 he managed to catch the first oncogenic virus, type 16, and a year later, the second - HPV-18. In recent years more than a hundred human papillomavirus genotypes are known, but only two of them: HPV-16 and HPV-18 - cause more than $70 \%$ of cases of anogenital cancer in both sexes. In 2008, Zur Hausen received the Nobel Prize in Physiology or Medicine for discovering the role of papillomaviruses in the development of cervical cancer, which he shared with Luke Montagnier and Francoise BarreSinoussi, who discovered the human immunodeficiency virus [16-18].

Some HPV genotypes have a carcinogenic effect leading to malignant transformation of cells. Human papillomaviruses include five evolutionary groups. HPV alpha group consists of more than 60 types [11-15, 19]. Viruses of this particular group affect the cervical epithelium and are most often detected in the tumor tissues of patients with cervical cancer. More than $90 \%$ of all papilloma viruses characterized today are in the Alpha and Beta groups. Papilloma viruses, which are part of the Beta, Gamma, Mu and Nu groups, parasitize in human skin cells.

According to the classification of viruses adopted at the 7th International Congress on Taxonomy, papillomavirus forms a family - Papillomaviridae. The Papillomaviridae family includes the following genera: Alphapapillomavirus, Betapapillomavirus, Gammapapillomavirus, Deltapapillomavirus, Epsilonpapillomavirus, Zetapapillomavirus, Etapapillomavirus, Thetapapillomavirus, Iotapapillomavirus, Kappapapillomavirus, Lambdapapillomavirus, Mupapillomavirus, Nupapillomavirus, Xipapillomavirus, Omikronpapillomavirus, Pipapillomavirus.

Alphapapillomavirus (HPV-2, HPV-3, HPV-6, HPV-7, HPV-10, HPV-13, HPV-16, HPV-18, HPV26, HPV-28, HPV-32, HPV-33, HPV-34, HPV-40, HPV-42, HPV-45, HPV-52, HPV-53, HPV-54, HPV-55, HPV- 57, HPV-61, HPV-66, HPV-67, HPV-68, HPV-69, HPV-71, HPV-77, HPV-81, HPV84, HPV-cand85, HPV-cand86, HPV-cand89, HPV-cand90, HPV-cand91, HPV-94, PCPV-1, RhPV-1) Members of this genus most often affect the mucosa of the face and anogenital area. For some types (HPV 2, $10)$, skin lesions are more characteristic.

Betapapillomavirus (HPV-4, HPV-5, HPV-9, HPV-12, HPV-14D, HPV-17, HPV-20, HPV-23, HPV- 25, HPV-38, HPV-47, HPV-48, HPV-49, HPV-50, HPV-60, HPV-65, HPV-75 HPV-88, HPVcand92, HPV-cand96, BPV-1, BPV-2, DPV, OvPV-1, OvPV-2). Members of this genus most often affect the skin. An infection is characterized by a latent course and activation during the development of immunodeficiency. HPV types 9, 49 are associated with veruciform epidermodysplasia.

Epsilonpapillomavirus (BPV (Bovine papillomavirus)-5). Infection causes cutaneous papillomas in cattle. horses.

Zetapapillomavirus (EcPV (Equus caballus papillomavirus) 1, EcPV). Infection causes skin lesions in

Etapapillomavirus (FcPV (Fringilla coelebs papillomavirus), ChPV (Chaffinch papillomavirus)). Infection causes skin lesions in birds. in birds

Thetapapillomavirus (PePV (Psittacus erithacus timneh papillomavirus)). Infection causes skin lesions

Iotapapillomavirus (MNPV (Mastomys natalensis papillomavirus)). Infection causes skin lesions in rodents.

Kappapapillomavirus (CRPV (Cottontail rabbit papillomavirus), ROPV (Rabbit oral papillomavirus)). Infection causes damage to the skin and mucous membranes in rabbits. 
Lambdapapillomavirus (COPV (Canine oral papillomavirus), FDPV (Felis domesticus papillomavirus)). Infection causes damage to the skin and mucous membranes in dogs and cats.

Mupapillomavirus (HPV-1, HPV-63). Infection causes skin lesions in humans.

Nupapillomavirus (HPV-41). The infection causes malignant lesions of the skin and soft tissues in humans.

Xipapillomavirus (BPV (Bovine papillomavirus)-3, BPV-4, BPV-6). The infection causes true papillomas of the skin and mucous membrane of cattle.

Omikron Papillomavirus (PsPV (Phocoena spinipinnis papillomavirus)). Infection causes genital warts in cetaceans.

Pipapillomavirus (HaOPV Hamster oral papillomavirus). Infection causes mucosal lesions in hamsters. To date, more than 300 new papillomaviruses that have not yet been included in the taxonomy have been identified $[11-15,19]$.

The oncogenic potential of HPV types varies significantly. According to their ability to initiate dysplastic (precancerous) changes, HPV genotypes are conditionally divided into groups of «high», «medium» and «low» risk of tumor transformation of infected epithelium (see Table 1). So, HPV types 6 and 11 are often the cause of genital warts, sometimes they are found in mild and moderate dysplasia, and they are extremely rarely associated with cervical tumors. Cervical cancer is most often caused by human papillomaviruses from the Alpha-5, -6, -7, - 9 and -11 groups. HPV types 16 and 18 are found in $80-90 \%$ of cases of cervical cancer [19].

$\mathrm{Tab}$ a 1

\section{Classification of HPV types by their oncogenic activity}

\begin{tabular}{|c|c|c|}
\hline HPV low oncogenic risk & HPV medium oncogenic risk & HPV high oncogenic risk \\
\hline HPV $6,11,42,43,44$ & HPV $31,33,35,51,52,58$ & HPV 16,18, 39,45, 56,59 and 68 \\
\hline
\end{tabular}

HPV type 2 is known to affect mainly the skin, causing the appearance of warts. HPV types 6 and 11 are considered to be of low oncogenic risk and are associated with the development of genital warts (multiple outgrowths of connective tissue covered with stratified squamous epithelium) and mild cervical intraepithelial neoplasia (CIN) [20,21]. For type $11 \mathrm{HPV}$, association with condylomas of the larynx has also been proven $[22,23]$.

The human papillomavirus has long been considered the cause of skin and genital warts. More recently, it has been proven that viruses of this family induce benign and malignant tumors in humans. Carcinogenicity was first proven for HPV types 16 and 18, as indicated in the WHO Newsletter (1996) [24].

Table 2

Diseases caused by human papilloma viruses

\begin{tabular}{|c|l|c|l|}
\hline $\begin{array}{c}\text { Type } \\
\text { of virus }\end{array}$ & \multicolumn{1}{|c|}{ Diseases } & $\begin{array}{c}\text { Type } \\
\text { of virus }\end{array}$ & \multicolumn{1}{|c|}{ Diseases } \\
\hline HPV-1 & Plantar warts & HPV-11 & $\begin{array}{l}\text { Laryngeal papillomas and condylomas; cervical } \\
\text { cancer }\end{array}$ \\
\hline HPV-2 & Conventional warts on the hands & HPV-12 & $\begin{array}{l}\text { Warty epidermodysplasia (degenerates into malig- } \\
\text { nant) }\end{array}$ \\
\hline HPV-3 & Flat warts; warty epidermodysplasia & HPV-13 & Focal oral hyperplasia \\
\hline HPV-4 & Plantar warts & HPV-14 & Warty epidermodysplasia \\
\hline HPV-5 & $\begin{array}{l}\text { Flat warts; warty epidermodysplasia (degen- } \\
\text { erating into malignant) }\end{array}$ & HPV-15 & Warty epidermodysplasia \\
\hline HPV-6 & Genital warts; cervical cancer & HPV-16 & Cervical cancer; papularity type Bowen's disease \\
\hline HPV-7 & Butcher's papillomas & HPV-18 & Cervical cancer \\
\hline HPV-8 & $\begin{array}{l}\text { Warty epidermodysplasia (degenerating into } \\
\text { malignant) }\end{array}$ & HPV-39 & Cervical cancer \\
\hline HPV-9 & $\begin{array}{l}\text { Flat warts; warty epidermodysplasia (degen- } \\
\text { erating into malignant) }\end{array}$ & HPV-45 & Cervical cancer \\
\hline HPV-10 & $\begin{array}{l}\text { Flat warts; warty epidermodysplasia (degen- } \\
\text { erating into malignant); cervical cancer; can- } \\
\text { cer of the external female genital organs }\end{array}$ & HPV-56 & Cervical cancer \\
\hline
\end{tabular}


For the human anogenital region, 14 types of HPV of a high degree of oncogenic risk are specific [25, 26]. HPV 16, 18, 31, 33, 35, 36, 39, 45, 52, 56, 58, 59, 66, penetrating into the transition zone of the cervix, they cause CIN I, II, III degree and carcinoma. HPV of these types is found in 50-80\% of samples with CIN II, III degree and in $90 \%$ of invasive cancer. The number of DNA copies of human papilloma viruses in cervical samples depends on the severity of the lesion and on the type of HPV.

N. Muñoz and co-author (2003) [27] summarized the results of 11 epidemiological studies conducted in 9 countries of the world and proposed the following epidemiological classification of HPV types associated with diseases of the genital tract. Types $6,11,40,42,43,44,54,61,70,72,81$ and CP6108 were classified as low risk types of cervical cancer, types $16,18,26,31,33,35,39,45,51,52,53,56,58,59,66,68,73$ and 82 - high risk type. HPV types 16 and 18 prevalence in cervical cancer prevails over other types of papillomaviruses: HPV type 16 is detected in 50-70 \% of cases, type 18 in 10-20\%. Types 16, 18, 31, 33, 35, 45, 52 , and 58 are responsible for $95 \%$ of all cases of squamous cell carcinomas, other types of high-risk HPV are found much less frequently [28].

Papillomaviruses have relatively small virions lacking a membrane membrane. According to various literature sources $[2,3,5,13]$, their diameter is about $30-55 \mathrm{~nm}$. The virus remains at a temperature of $50{ }^{\circ} \mathrm{C}$ for 30 minutes, is resistant to ethers and alcohols. The virion contains two layers of structural proteins, denoted by the letter E. The internal proteins connected to the DNA are cellular histones, and the capsid proteins are type-specific antigens. HPV reproduction occurs in the nuclei of cells where viral DNA is present as an episoma. This is the first feature that distinguishes HPV from other oncogenic DNA-containing viruses (hepatitis B virus - the family of padnaviruses and Epstein-Barr virus - the family of herpes viruses), which can integrate their genome into the DNA of the transformed cell. The second feature is that the state of the host cell regulates the expression of the viral genome. However, the viral gene responsible for cell DNA replication can also be transcribed, resulting in the host cell sharing again and again with HPV, which leads to a productive type of inflammation. HPV infects epithelial cells, causing the appearance of skin warts and papillomas of the mucous membrane of the genitourinary, respiratory tract and digestive tract [29].

HPV capsid consists of 72 pentamer capsomeres. The capsid of papillomaviruses has a spherical shape, but in reality it is an icosahedron with a triangulation number equal to seven. The spherical structure is formed not from a combination of hexamers and pentamers (as, for example, in a soccer ball), but from two types of pentamers. 60 pentamers of the HPV capsid form 6 bonds with neighboring pentamers, and 12 of them - five each $[19,29]$. The structure of the human papillomavirus is shown in Figure 1.

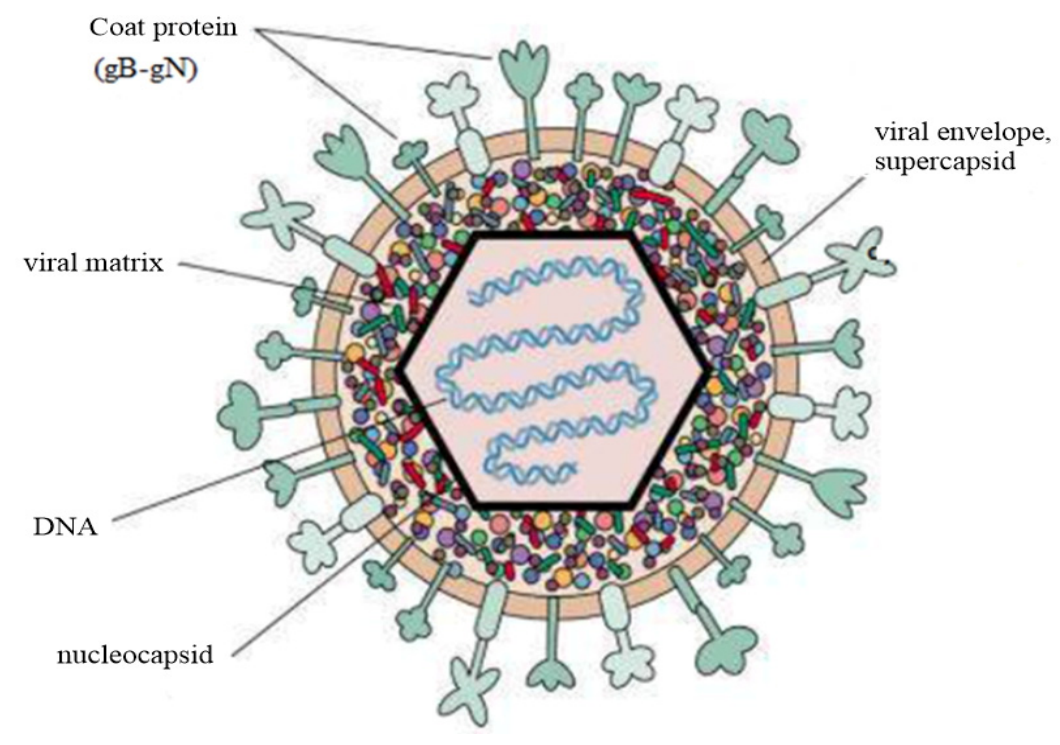

Figure 1. The structure of the human papillomavirus

The HPV genome is a cyclically closed double-stranded DNA with a molecular weight of 3-5 $\mathrm{mD}$ and a size of 8,000 pairs of nucleotides. The DNA of the HPV genome, which is packed with histones - cellular proteins involved in the compaction of DNA in the nucleus. Functionally, the HPV genome is divided into three active regions: Long control region (LCR), early (E), late (L) and encodes two types of proteins. During the replication cycle, the virus genome expresses from 8 to 10 protein products. Early proteins (early proteins, 
E-proteins) carry out regulatory functions, ensure the reproduction of the virus and, in some cases, are responsible for malignant degeneration of cells. Late proteins (L-proteins) perform a structural function, forming a capsid of virions. The long control section (LCR) of human papillomavirus type 16 (HPV-16) has a size of 850 bp (about $12 \%$ of the viral genome) and regulates the transcription and replication of viral DNA. The 5'segment of LCR contains transcription termination signals and the attachment region of the nuclear matrix, the central segment contains an enhancer specific for epithelial cells, and the 3'-segment contains a replication source and an E6 promoter. The LCR region is involved in the regulation of transcription of viral genes [19, 29, 30]. Region E includes early genes (E6, E7, E1, E2, E4, E5) encoding early proteins. Late genes (L1, L2) encode structural proteins of the virion. A map of the HPV 16 genome is shown in Figure 2.

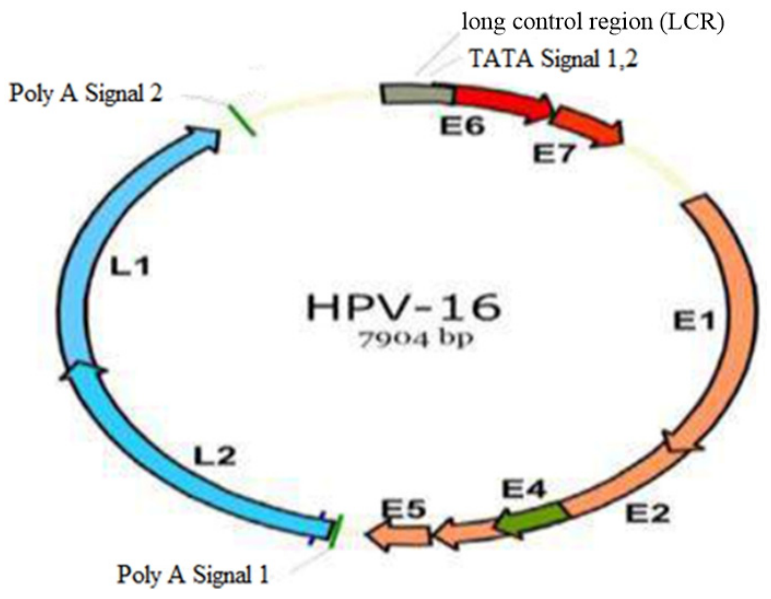

Figure 2. HPV genome map 16

Interestingly, the structure of L1 resembles the structure of cellular proteins of nucleoplasmins that regulate the packaging of nucleosomes $[19,29,30]$. At the moment, there is no exact understanding of whether L1 and nucleoplasmins have a common ancestor, or their similarity is the result of convergent evolution. How exactly is the DNA laid inside the virus particle, is also not fully described. It is known that any DNA shorter than 8 thousand nucleotide pairs can be packaged into virus-like particles of HPV, which opens up prospects for using HPV as transformation vectors. Interestingly, cyclophilin, a cellular protein also contributing to the unpacking of the HIV capsid, is involved in the unpacking of the papillomavirus capsid.

Only 18 strains lead to malignant neoplasms (this applies to cervical cancer and the anogenital zone). Human papillomavirus (HPV) is transmitted mainly through sexual contact and mucosal contact. It is believed that low-risk HPVs produce more virions, spread better, although they are eliminated from the body in one to two years, or even faster [13]. Compared to them, high-risk strains infect fewer people, but the immune system is more difficult to cope with. The most carcinogenic are HPV 16 and HPV 18 strains, and HPV 6 and HPV 11 strains are responsible for the occurrence of warts in the anogenital zone in $90 \%$ of cases. It is these papillomavirus representatives that attract the most attention of researchers $[25,29,30]$.

The life cycle of papilloma viruses is tied to the stages of keratinocyte development. Actively dividing young keratinocytes line the basement membrane located under the upper layers of the epidermis, and as they mature and differentiate, the keratinocytes are displaced to the skin surface. Viral particles infect cells that have not yet differentiated, and new particles are formed in keratinocytes that have reached the terminal stage of differentiation. Cervical carcinomas are the most common type of tumor originating from keratinocytes. The key event in the malignant transformation of epithelial cells is the integration of viral DNA into the DNA of the host cell. The integration process is accompanied by the destruction of the open reading frames of the E1 and E2 virus genes, whose products are involved in the regulation of the expression of oncogenic proteins of the E6 and E7 virus. It is believed that the integration of viral DNA into the host DNA results in a significant increase in the expression of E6 and E7 proteins, which disable two key proteins (p53 and $\mathrm{pRb}$ ) that regulate the cell cycle $[30,31]$.

Early papillomavirus proteins provide the desired content of virus DNA in the cell nucleus and coordinate the expression of its genes. Three early genes (E1, E2, E4) control the functions necessary for the reproduction of the virus, and $\mathrm{E} 2$ has the functions of a regulator of transcription of viral DNA, which begins in the regulatory region of LCR. Proteins E1 and E2 form a complex with the DNA of the virus, attracting cel- 
lular replication systems. Genes E5, E6, E7 possess activity that stimulates the proliferation and transformation of cells $[30,32]$. The early proteins E6 and E7 are responsible for the carcinogenic effect in HPV strains of high carcinogenic risk; they are always detected in the tumor cells of infected HPV, while other fragments of the viral genome may be lost during its long-term persistence. At the same time, the HPV E6 protein is able to bind to the tumor suppressor with the 53 protein followed by its ubiquitination and degradation, and the E7 protein binds and affects the work of a number of $\mathrm{pRb}, \mathrm{p} 107, \mathrm{p} 130$ and $\mathrm{p} 21^{\text {Cip } 1}$ proteins, which are regulatory proteins and tumor suppressors. Protein E6 also activates telomerase, which allows infected cells to avoid aging. Interactions of E6 / p53 and E7 / pRb lead to a malfunction of the cell cycle with loss of control over DNA repair and replication, leading to uncontrolled cell division. Thus, polymorphism of the gene encoding p53 is a genetic predisposition for the active development of HPV with cell malignancy [30-34].

Later HPV proteins are needed for capsid formation and packaging of the virus DNA. The main structural component of the papillomavirus capsid is the L1 protein, which forms pentamers. The minor protein L2 is also a structural component of the viral particle. One L2 falls on one pentamer L1. Apparently, this protein is important for attracting viral DNA to collecting particles. There is a hypothesis that L1 and L2 can interact not directly with the nucleic acid of the virus, but with the histones that compact it [19,29-34].

In the line of immortal HeLa cells originating from cervical tumor tissue, p53 and pRb signaling pathways are repressed by oncoproteins. When the expression of E6 and E7 proteins is lost by the HPV virus, the $\mathrm{p} 53$ and $\mathrm{pRb}$ signaling pathways can be reactivated. Being in the cell in an episomal state, HPV for a long time may not show its suppressive effect. During neoplastic transformation, viral DNA is integrated into the genome of the epithelial cell, which is accompanied by a violation of the open reading frame of the E2 viral gene. The function of the E2 gene is to repress the regulatory region of the viral promoter (UTR), which controls the transcription of the E6 and E7 genes, so that the loss of E2 gene activity is accompanied by the initiation of expression of the E6 and E7 genes. The expression of these genes can be inhibited in Notchl proteininfected keratinocytes. In such cells, the expression of the activated form of Notchl-Nicd causes suppression of proliferation, which may result from inhibition of the expression of proteins E6 and E7. Activation of transcription of the E6 and E7 proteins is accompanied by the interaction of their products with negative regulators of cell proliferation - proteins $\mathrm{p} 53$ and $\mathrm{pRb}$, functional inactivation of these proteins and activation of cell proliferation (see Fig. 3).

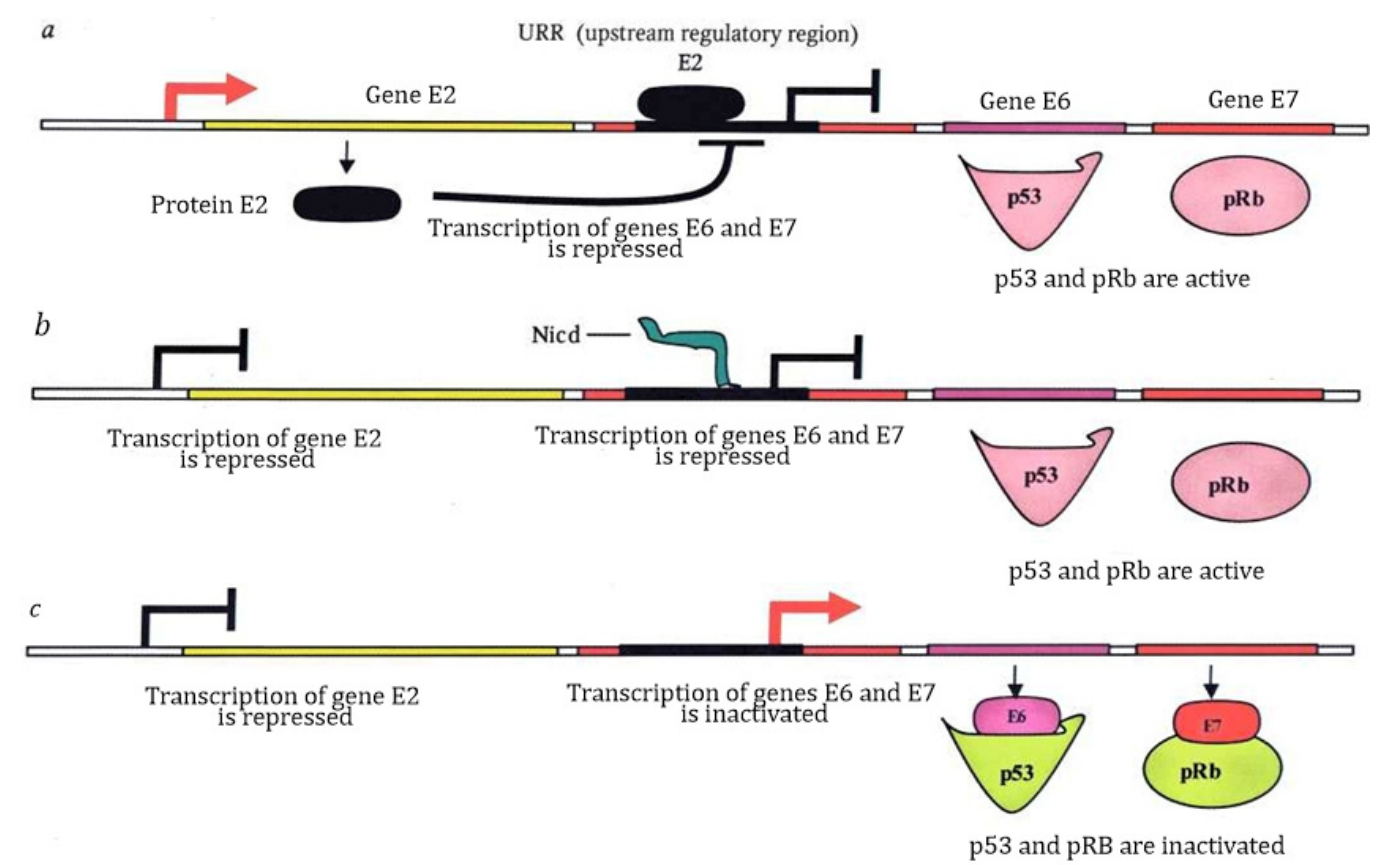

$a$ - in an episomal state, the virus does not show its suppressive effect; $b$ - expression of the E6 and E7 genes of the virus in infected keratinocytes can be inhibited by the active form of the Notchl-Nied protein; c - activation of transcription of proteins E6 and E7 is accompanied by functional inactivation of p53 and pRb and cell transformation

Figure 3. The role of Notch signals in the occurrence of cervical cancer induced by the human papillomavirus [29] 
Despite the fact that the phenomenon of integration of viral DNA into the host genome is being actively studied, the available data do not allow us to unambiguously assess its clinical significance. As a rule, in the early stages of the tumor process, viral DNA is detected in episomic form, while in the later stages, in integrated form $[6,33]$. Recently, a highly sensitive method for determining the physical status of HPV type 16 using real-time PCR has been proposed, with which an integrated form of the virus was detected at the very early stages of the disease, when there was no cytological evidence of neoplastic changes [35].

Cervical cancer of the uterus is preceded by cervical intraepithelial neoplasia, which according to the severity is usually divided into mild, moderate and severe dysplasia. In most cases of mild to moderate dysplasia, spontaneous regression occurs, and only in 10-20\% of cases the disease progresses to cervical cancer. Establishing the central role of oncogenic types of HPV in the etiology of cervical cancer has led to the emergence of new strategies for the prevention of this disease. These include the development of vaccines against oncogenic types of the virus and the inclusion of an HPV test in cervical cancer screening. Numerous studies have shown that the HPV test has a much higher sensitivity for detecting cervical intraepithelial neoplasia than a traditional cytological study. However, the HPV test has rather low specificity and prognostic significance of positive results, since in most women, especially young women, human papillomavirus infection (PVI) is transient in nature.

According to experts, by far the most reliable prognostic indicator of disease progression is the identification of persistent PVI in women. It has been shown that the risk of persistence and subsequent progression is higher in cases of PVI with a higher viral load of HPV. However, the use in clinical practice of high viral load as a factor in neoplastic progression currently remains problematic for several reasons. Firstly, the dependence of the degree of dysplasia on the viral load has been adequately described only for type $16 \mathrm{HPV}$, and secondly, due to the lack of a standardized methodology for determining the amount of viral DNA, a threshold value cannot be set above which it can be considered clinically significant.

Many authors evaluate the definition of viral load and the integrated form of HPV viral DNA as molecular markers of the transforming activity of HPV, however, the possibility of their use in clinical practice remains to be assessed.

HPV DNA can be found in tumor cells in two forms - episomal and integrated. The biological significance of the integration of viral DNA with the host genome is still unclear. The integration process is accompanied by a partial loss of the genetic material of the virus, while the viral genome loses its ability to fully replicate, and there is no production of viral particles in cells containing the integrated cellular genome. However, integration may be a key event in cervical carcinogenesis, as it is very often associated with neoplastic progression. The most important integration result is considered to be an increase in the stability of E6 and E7 transcripts and violation of the intactness of the E2 gene that regulates their transcription [36-38]. For HPV types 16 and 18, it was shown that when integrating viral DNA into the host DNA, ORFs of El and E2 genes are usually destroyed, while ORFs E6 and E7, as well as LCR, remain intact [39]. Mapping deletions and destruction of ORF genes of El and E2 in a large series of carcinoma tissues positive for type 16 HPV revealed multiple sites of deletions, but ORF E2 deletions corresponding to the so-called hinge region of the protein are most common [40,41].

The disappearance of the suppressor function of the E2 protein causes an increase in the expression of E6 and E7, the transforming effect of which contributes to the progression of neoplasia [42]. It is assumed that the El gene is involved in the suppression of the viral promoter: an El gene mutation results in activation of the transcription of the viral genome and an increase in the transforming activity of viral oncogenes [41].

It is believed that integration is an activation mechanism of progression from severe dysplasia to cancer; it is initially polyclonal in nature [43]. Most often, certain sections of chromosomes 5, 6, 10, 11, and 17 are involved in carcinogenesis of the cervix uteri. The site of the predominant integration of viral DNA has not been determined, it is often located near cellular oncogenes [44]. Apparently, a secondary role in the regulation of the functions of viral oncogenes and the progression of the disease belongs to secondary genetic changes. The functioning of viral oncoproteins causes destabilization of the chromosomes, which may be the cause of activation of oncogenes or inactivation of suppressor genes. A study of the role of oncogenes in the pathogenesis of cervical cancer did not reveal any fundamental changes in the expression of most of them, with the exception of c-myc, c-fos and epidermal growth factor, and the expression of epidermal growth factor in the early stages indicates a poor prognosis [45].

The analysis of specific chromosomal abnormalities to identify areas of localization of potential suppressor genes inactivated during tumor progression was carried out by cytogenetic methods (FISH) or by analyzing the loss of heterozygosity (LOH). Alleleotyping of DNA revealed a high percentage of allelic 
losses on chromosomes $3,4,5,6,11$, and 18. It is interesting that the loci in which the TP53 (17p) and RB (13p) suppressor genes are located do not have a high deletion frequency. On chromosome 3, there are multiple allelic losses at the loci Zp14.2, 3p21.3, Zp24 and Zp25-26, and on Zp14.2 the FHIT gene is located, which is also deleted in tumors of the kidneys, lungs, and mammary gland, but it is not a true suppressor [46]. Of particular interest is the analysis of chromosome 6p, on which the genes of the main histocompatibility complex are located: a loss of heterozygosity in the zone of location of the HLA class I and TNF genes (6p22-21.3) was found in $50 \%$ of tumors. However, a comprehensive study of the genotype and phenotype of the HLAI class showed that up to $90 \%$ of tumors have certain structural changes and expression disorders. These disorders seem to play a crucial role in the ability of tumor cells to escape the immune response [46-49].

Frequent allelic deletions have also been found at locus 6q 16-21, where the suppressor gene and the aging inducing gene are believed to be located. The importance of certain genetic disorders can be assessed by correlation with the clinical stages of the disease. Disorders at the loci Zp14.2 and 6p21.3 appear at the stage of dysplasia, while the loss of heterozygosity at loci 6q16-21 and 1Ts22-23 correlates with the appearance of metastases. Thus, there is reason to believe that potential suppressor genes are located at these loci, which are to be identified [49]. Attempts are being made to identify specific genetic abnormalities in the epithelial cells of the cervical canal of the cervix uteri in carriers of BOT until signs of morphological atypia appear, which may be of practical importance in the early stages of the disease, especially in disputed cases.

The use of modern diagnostic algorithms and the widespread use of molecular biological methods have revealed dozens of types of human papillomaviruses that differ in their epidemiological role. Currently, more than 80 types of HPV have been identified that are specific for tropism to various tissues. Recognizing the crucial role that some specific types of HPV play in the development of cervical cancer is very important for their prevention and public health strategies for cervical cancer, which are still the leading cause of death among cancer patients in many countries.

\section{References}

1 Золотоверхая Е.А. Роль вирусологических факторов в развитии рака шейки матки у женщин репродуктивного возраста / Е.А. Золотоверхая, Л.А. Евстигнеева, Е.В. Бахидзе, В.В. Семиглазов, Е.В. Шипицына // Новые технологии в акушерстве и гинекологии: тез. докл. III Междунар. науч. конгр., посвящ. 210-летию НИИ акушерства и гинекологии им. Д.О. Отта PAMН // Журнал акушерства и женских болезней. — 2007. - T. LVII, Спец. вып. — C. 153, 154.

2 Долгополова И.А. Папилломавирусная инфекция: клиника, диагностика, лечение / И.А. Долгополова // Педиатрическая фармакология. - 2007. - Т. 4, № 1. - С. 56-60.

3 Молочков В.А. Папилломавирусная инфекция: пос. для врачей / В.А. Молочков, В.И. Кисилев, И.В. Рудных, С.Н. Щербо. - М.: ИД «Русский врач», 2004. - 35 с.

4 Киселёв В.А. Этиологическая роль вируса папилломы человека в развитии рака шейки матки: генетические и патогенетические механизмы / В.А. Киселёв, О.И. Киселёв // Цитокины и воспаление. — 2003. - Вып. 4. — С. 31-38.

5 Погосян Г.П. Определение вируса папилломы человека высокого канцерогенного риска / Г.П. Погосян, А.А. Коновалова, О. Царегородцева // Европейская наука XXI века: материалы IX Междунар. науч.-практ. конф. (7-15 мая 2015). - Пшемысль, 2015. - С. 26-29.

6 Чуруксаева О.Н. Рак шейки матки и вирусы папиллом / О.Н. Чуруксаева, Л.А. Коломиец, Л.Н. Уразова, Н.В. Севостьянова // Научная электронная библиотека «КиберЛенинка» - [ЭР]. Режим доступа: https://cyberleninka.ru/article/n/rak-sheyki-matki-i-virusy-papillom.

7 Жубатова Л. Папилломавирусная инфекция женских гениталий: отдельные грани проблемы (обзор литературы) / Л. Жубатова // Вестн. КазНМУ. — 2013. — № 4(1). — С. 103-106.

8 Кондриков Н.И. IX Всемирный конгресс по патологии шейки матки и кольпоскопии / Н.И. Кондриков, В.Н. Прилепская // Акушерство и гинекология. - 1996. - № 6. - С. 51, 52.

9 Новиков А.И. Инфекции, передаваемые половым путем, и экзоцервикс / А.И. Новиков, А.В. Кононов, И.Г. Ваганова. - М.: Медицина, 2002. - С. 176.

10 Monsonego J. Genital human papillomavirus infections / J. Monsonego // Journal HIV and AIDS. — 1993. — Vol. 4(1). P. 13-20.

11 Нарвская О.В. Вирус папилломы человека. Эпидемиология, лабораторная диагностика и профилактика папилломавирусной инфекции / О.В. Нарвская // Инфекция и иммунитет. - 2011. — Т. 1, № 1. — С. 15-22.

12 Золотоверхая Е.А. Применение метода ПЦР в реальном времени для определения вирусной нагрузки и статуса ДНК вируса папилломы человека 16 типа / Е.А. Золотоверхая, Е.В. Шипицына, Н.А. Микая, А.М. Савичева // Генодиагностика инфекционных болезней: сб. тр. 5-й Всерос. науч.-практ. конф. - М., 2004. - Т. 1. — С. 341-343.

13 Воробьев А.А. Атлас по медицинской микробиологии, вирусологии и иммунологии: учеб. пос. для студ. мед. вузов / А.А. Воробьев, А.С. Быков. - М.: Мед. информ. агентство, 2003. - С. 113.

14 Адамс М.Дж. Ратификация голосования по таксономическим предложениям в Международный комитет по таксономии вирусов / М.Дж. Адамс, Э.Б. Карстенс // Архив вирусологии. - 2012. — Т. 157, Вып. 7. - С. 1411-1422. 
15 Папилломавирусы человека / Wikipedia - [ЭР]. Режим доступа https://ru.wikipedia.org/wiki

16 Склут Р. Бессмертная жизнь Генриетты Лакс / Р. Склут. - М.: Карьера Пресс, 2012. — 384 с.

17 Паевский А. Увидевший вирусы в раке. Харальд цур Хаузен / А. Паевский // Биомолекула. — [ЭР]. Режим доступа https://biomolecula.ru/articles/uvidevshii-virusy-v-rake-kharald-tsur-khauzen.

18 Паевский А. Нобелевские лауреаты: Харальд цур Хаузен. Человек, соединивший вирусы и рак / А. Паевский // Indicator. - [ЭР]. Режим доступа https://indicator.ru/medicine/harald-cur-hauzen.htm.

19 Поляниченко А.А. Строение и классификация вирусов папилломы человека (литературный обзор) / А.А. Поляниченко // Перспективы развития современной медицины: Сб. науч. тр. по итогам Междунар. науч.-практ. конф. - № 2 . Воронеж, 2015. - $206 \mathrm{c}$. $88 \mathrm{c}$.

20 Прилепская В.Н. Заболевания шейки матки: Клинические лекции / В.Н. Прилепская. — М.: Медиа-Сфера, 1997. -

21 Прилепская В.Н. Возрастные особенности шейки матки. Современные методы диагностики патологии шейки матки / В.Н. Прилепская // Акушерство и гинекология. - 1998. — № 6. - С. 51-54.

22 Русакевич П.С. Заболевания шейки матки: симптоматика, диагностика, лечение, профилактика: справоч. пос. / П.С. Русакевич. - Минск: Высш. шк., 2000. - 368 с.

23 Хмельницкий О.К. Цитологическая и гистологическая диагностика заболеваний шейки и тела матки / О.К. Хмельницкий. - СПб.: СОТИС, 1999. - 336 с.

24 Скрининг рака шейки матки в развивающихся странах: докл. о консультации ВO3 / WHO. — [ЭР]. Режим доступа https://www.who.int/ru/

25 Погосян Г.П. Определение генотипов вируса папилломы человека / Г.П. Погосян, В.В. Протас, А.А. Коновалова, К.Г. Ли // Молекулярная диагностика - 2014: сб. тр. VIII Всерос. науч.-практ. конф. с междунар. участием. - М.: ООО «Интерлабсервис», 2014. - С. 185, 186.

26 Погосян Г.П. Амплификация ДНК некоторых вирусных агентов / Г.П. Погосян, К.Г. Ли, А.Г. Жумина // II Междунар. науч.-практ. конф. молодых ученых (18-19 апреля). - Тараз, 2007. - С. 130-135.

27 Munoz N. Epidemiologic classification of human papillomavirus types associated with cervical cancer / N. Munoz, F.X. Bosch, S. de Sanjose et al. // New England Journal of Medicine. — 2003. - Vol. 348(6). — P. 518-527.

28 Syijanen, K. Epidemiology of human papillomavirus infection and genital neoplasia / K. Syrjanen, S. Syijanen // Scand. J. Infect. Dis. Suppl. — 1990. - Vol. 69. - P. 7-17.

29 Стефанов Ю. Вирус папилломы человека (ВПЧ) / Ю. Стефанов // Visual-Science — [ЭР]. Режим доступа: https://visual-science.com/ru/projects/human-papillomavirus/illustration

30 Попов Б.В. Введение в клеточную биологию стволовых клеток: учеб.-метод. пос. / Б.В. Попов. - СПб.: СпецЛит, 2010. $-319 \mathrm{c}$.

31 Клаг С.У. Основы генетики / У.С. Клаг, М.Р. Каммингс, Ш.А. Спенсер. - М.: Техносфера, 2017. — 944 с.

32 Кребс Дж. Гены по Льюину / Дж. Кребс, Э. Голдштейн, С. Килпатрик. — М.: Лаборатория знаний, 2018. — 919 с.

33 Zur Hausen H. Papillomavirus infections are the main cause of human cancer / H. Zur Hausen // Biochimica et Biophysica Acta (BBA). - 1996. - Vol. 1288, Iss. 2. - P. 55-78.

34 Альбертс Б. Основы молекулярной биологии клетки / Б. Альбертс, Д. Брей, К. Хопкин, А. Джонсон, Дж. Льюис, М. Рэфф, К. Робертс, П. Уолтер. - М.: Бином. Лаборатория знаний, 2015. — 768 с.

35 Погосян Г.П. Определение ДНК некоторых вирусов методом полимеразной цепной реакции / Г.П. Погосян, А.А. Коновалова, В.В. Протас // Современная ботаника: биоразнообразие, биоресурсы, биотехнологии: материалы Междунар. науч.-практ. конф. (27-28 ноября 2014 г.). — Караганда: Изд-во КарГУ, 2014. — С. 319-323.

36 Jeon S. Integration of human papillomavirus type 16 DNA into the human genome leads to increased stability of E6 and E7 mRNAs: implications for cervical carcinogenesis / S. Jeon, P.F. Lambert // Proceedings of the National Academy of Science USA. — 1995. - Vol. 92. - P. 1654-1658.

37 Bechtold V. Human papillomavirus type 16 E2 protein has no effect on transcription from episomal viral DNA / V. Bechtold, P. Beard, K. Raj // The Journal of Virology. — 2003. - Vol. 77. — P. 2021-2028.

38 Tan S.H. The human papillomavirus type $16 \mathrm{E} 2$ transcription factor binds with low cooperativity to two flanking sites and represses the E6 promoter through displacement of Spl and TFIID / S.H. Tan, L.E. Leong, P.A. Walker, H.U. Bernard // The Journal of Virology. - 1994. - Vol. 68. - P. 6411-6420.

39 Daniel, B. The link between integration and expression of human papillomavirus type 16 genomes and cellular changes in the evolution of cervical intraepithelial neoplastic lesions / B. Daniel, A. Rangarajan, G. Mukheijee, et al. // The Journal of General Virology. - 1997. - Vol. 78. - P. 1095-1101.

40 Stunkel W. Nuclear matrix attachment regions of human papillomavirus type 16 repress or activate the E6 promoter, depending on the physical state of the viral DNA / W. Stunkel, Z. Huang, S.H. Tan, e1 al. // The Journal of Virology. - 2000. - Vol. 74. - P. 2489-2501.

41 Romanczuk H. Disruption of either the E1 or the E2 regulatory gene of human papillomavirus type 16 increases viral immortalization capacity / H. Romanczuk, P.M. Howley // Proceedings of the National Academy of Science USA. — 1992. - Vol. 89. P. 3159-3163.

42 Hou S.Y. Transcriptional activity among high and low risk human papillomavirus E2 protein correlates with E2 DNA binding / S.Y. Hou, S.Y. Wu, C.M. Chiang // The Journal of Biological Chemistry. — 2002. — Vol. 277. — P. 45619-45629.

43 Ueda Y. Monoclonal expansion with integration of high-risk type human papillomaviruses is an initial step for cervical carcinogenesis: association of clonal status and human papillomavirus infection with clinical outcome in cervical intraepithelial neoplasia / Y. Ueda, T. Enomoto, T. Miyatake, et al. // Laboratory Investigation (journal). — 2003. — Vol. 83. - P. $1517-1527$.

44 Thorland E.C. Common fragile sites are preferential targets for HPV16 integrations in cervical tumors / E.C. Thorland, S.L. Myers, B.S. Gostout, D.I. Smith // Oncogene (journal). — 2003. — Vol. 22. — P. 1225-3127. 
45 Mullokandov, M.R. Genomic alterations in cervical carcinoma: losses of chromosome heterozygosity and human papilloma virus tumor status / M.R. Mullokandov, N.G. Kholodilov, N.B. Atkin, et al. // Cancer Research. — 1996. — Vol. 56. - P. $197-202$.

46 Goldie S.J. Analysis of intratumoral heterogeneity of chromosome 3p deletions and genetic evidence of polyclonal origin of cervical squamous carcinoma / S.J. Goldie, F. Wu, A. Asplund, et al. // Modern Pathology. — 2001. — Vol. 14. — P. 54-61.

47 Harald Zur Hausen. Papillomaviruses and cancer: from basic studies to clinical application / H. zur Hausen // Nature Reviews Cancer. - 2002. - Vol. 2. - P. 342-350.

48 Mazurenko, N. High resolution mapping of chromosome 6 deletions in cervical cancer / N. Mazurenko, M. Attaleb, T. Gritsko et al. // Oncology Reports. - 1999. - Vol. 6. - P. 859-863.

49 Koopman, L.A. Multiple genetic alterations cause frequent and heterogeneous human histocompatibility leukocyte antigen class I loss in cervical cancer / L.A. Koopman, W.E. Corver, A.R. Van Der Slik et al. // Journal of Experimental Medicine. - 2000. — Vol. 191. - P. 961-975.

\title{
К.А. Жумашева, Г.П. Погосян, Б.К. Жумашев, М. Даниленко
}

\section{Жоғары канцерогенді қауіпті адам папиллома вирусының генетикалық шарттылығы}

\begin{abstract}
Авторлар адам папиллома вирусының (АПВ) индукцияланған канцерогенездің негізгі концепцияларын және АПВ ішкі типті нұсқалар арасында кездесетін молекулалық айырмашылықтарды қарастырған, олардың клиникалық және функционалдық салдары берілген. Адамның папиллома вирусы (АПВ) - бұл кішкентай ДНҚ вирустардың әр түрлі тобы, олардың кейбіреулері соңғы отыз жыл ішінде канцерогендік потенциалына байланысты кеңінен зерттелген. Вирусты инфекциялардың төзімділігі және Е6 және Е7 вирусты онкогендердің бақыланбайтын экспрессиясы трансформация процесіндегі сыни оқиғалар болып табылады. Вирустық типтер жасушалардың әртүріне тән және әдетте әртүрлі қатерсіз немесе қатерлі ісіктерді тудыратын зақымдануларды атап өткеніміз жөн. Жатыр мойны қатерлі ісігінің дамуындағы АПВ-ның кейбір нақты түрлерінің маңызды рөлін мойындау олардың алдын-алу және көптеген елдерде онкологиялық аурулармен ауыратын адамдар арасында өлімнің басты себебі болып табылатын жатыр мойны ісігімен күресу үшін денсаулық сақтау стратегиялары өте маңызды болып табылады.
\end{abstract}

Кілт сөздер: Адам папиллома вирусы, жатыр мойнының ісігі, кератиноциттер, онкогенез, қатерлі трансформация, вирион, капсид, Е6 және Е7 вирустық онкогендер, p53 және pRb регуляторлық жасушалық ақуыздар, L1 және L2 минорлық белоктар, адам папиллома вирусын ұзақ бақылаушы аудан (LCR HPV), HeLa өлмейтін жасушалар линиясы.

\section{К.А. Жумашева, Г.П. Погосян, Б.К. Жумашев, М. Даниленко}

\section{Генетическая обусловленность вируса папилломы человека высокого канцерогенного риска}

\begin{abstract}
Авторами рассмотрены основные концепции индуцированного канцерогенеза вируса папилломы человека (ВПЧ) и молекулярные различия, обнаруженные среди типов ВПЧ и внутритипных вариантов, приведены их клинические и функциональные последствия. Вирус папилломы человека представляет собой разнообразную группу небольших ДНК-вирусов, некоторые из которых широко изучались в течение последних трех десятилетий в связи с их канцерогенным потенциалом. Стойкость вирусных инфекций и неконтролируемая экспрессия вирусных онкогенов Е6 и Е7 являются критическими событиями в процессе трансформации. Важно отметить, что вирусные типы специфичны для каждого типа клеток и обычно вызывают различные виды поражений: доброкачественные или злокачественные. Признание важнейшей роли, которую играют некоторые конкретные типы ВПЧ в развитии рака шейки матки, очень важно для их профилактики и реализации стратегий общественного здравоохранения по борьбе с раком шейки матки.

Ключевые слова: вирус папилломы человека, рак шейки матки, кератиноциты, онкогенез, злокачественная трансформация, вирион, капсид, вирусные онкогены Е6 и Е7, регуляторные клеточные белки p53 и pRb, минорные белки L1 и L2, длинный контрольный участок вируса папиломы человека (LCR HPV), линия бессмертных клеток HeLa.
\end{abstract}

\section{References}

1 Zolotoverhaya, E.A., Evstigneeva, L.A., Bakhidze, E.V., Semiglazov, V.V. \& Shipitsyna, E.V. (2007). Rol virusolohicheskikh faktorov $\mathrm{v}$ razvitii raka sheiki matki u zhenshchin reproduktivnoho vozrasta [The role of virological factors in the 
development of cervical cancer in women of reproductive age]. Zhurnal akusherstva i zhenskikh boleznei - Journal of Obstetrics and Women's Diseases, Special Issue, LVII, 153-154 [in Russian].

2 Dolgopolova, I.A. (2007). Papilomavirusnaia infektsiia — klinika, diahnostika, lechenie [Papillomavirus infection - clinic, diagnosis, treatment]. Pediatricheskaia farmakolohiia - Pediatric pharmacology, 1, 56-60 [in Russian].

3 Molochkov, V.A. (2004). Papillomavirusnaia infektsiia. Posobie dlya vrachei [Paillomovirus infection. Manual for doctors]. Moscow: ID «Russkii vrach» [in Russian].

4 Kiselev, V.A. (2003). Etiolohicheskaia rol virusa papillomy cheloveka v razvitii raka sheiki matki: Heneticheskie i patoheneticheskie mekhanizmy [Etiological role of human papillomavirus in the development of cervical cancer: Genetic and pathogenetic mechanisms]. Tsitokiny $i$ vospalenie - Cytokines and Inflammation, 4, 31-38 [in Russian].

5 Pogosyan, G.P., Konovalova, A.A. \& Tsaregorodtseva, O. (2015). Opredelenie virusa papillomy cheloveka vysokoho kantserohennoho riska [High carcinogenic risk determination of human papillomavirus]. Proceedings from 21st Century European Science'15: IX Mezhdunarodnaia nauchno-prakticheskaia konferentsiia - IX International Scientific and Practical Conference (May, 7-15) (pp. 26-29). Przemizl [in Russian].

6 Churuksaeva, O.N., Kolomiyets, L.A., Urazova, L.N. \& Sevostyanov, N.V. (2002). Rak sheiki matki i virusy papillom [Cervical Cancer and Papillomaviruses]. CyberLeninka Retrived from https://cyberleninka.ru/article/n/rak-sheyki-matki-i-virusy-papillom [in Russian].

7 Zhubatova, L. (2013). Papillomavirusnaia infektsiia zhenskikh henitalii: otdelnye hrani problemy (obzor literatury) [Papillomavirus infection of the female genitalia: individual facets of the problem (literature review)]. Vestnik Kazakhskoho natsionalnoho meditsinskoho universiteta - Bulletin of Kazakh National Medical University, 4(1), 103-106 [in Russian].

8 Kondrikov, N.I., \& Prilepskaya, V.N. (1996). IX Vsemirnyi konhress po patolohii sheiki matki i kolposkopii [IX World Congress on Cervical Pathology and Colposcopy]. Akusherstvo i hinekolohiia - Obstetrics and Gynecology, 6, 51-52 [in Russian].

9 Novikov, A.I., Kononov, A.V. \& Vaganova, I.G. (2002). Infektsii, peredavaemye polovym putem, i ekzotserviks [Sexually transmitted infections and exocervix]. Moscow: Meditsina [in Russian].

10 Monsonego, J. (1993). Genital human papillomavirus infections. Journal HIV and AIDS, 4(1), 13-20.

11 Narvskaya, O.V. (2011). Epidemiolohiia, laboratornaia diahnostika i profilaktika papillomavirusnoi infektsii [Epidemiology, laboratory diagnosis and prevention of human papillomavirus infection]. Infektsiia i immunitet - Infection and Immunity, 1(1), 1522 [in Russian].

12 Zolotoverhaya, E.A., Shipitsyna, E.V., Mikaya, N.A. \& Savicheva, A.M. (2004). Primenenie metoda PTSR v realnom vremeni dlia opredeleniia virusnoi nahruzki i statusa DNK virusa papillomy cheloveka 16 tipa [The use of real-time PCR to determine the viral load and DNA status of human papillomavirus type 16]. Proceedings from Genetic Diagnosis of Infectious Diseases'04: 5-aia Vserossiiskaia nauchno-prakticheskaia konferentsiia - 5th All-Russian Scientific and Practical Conference. (Vol. 1, pp. 341-343). Moscow [in Russian].

13 Vorobiev, A.A. \& Bykov, A.S. (2003). Atlas po meditsinskoi mikrobiolohii, virusolohii i immunolohii [Atlas of Medical Microbiology, Virology, and Immunology]. Moscow: Meditsinskoe informatsionnoe ahentstvo [in Russian].

14 Adams, M.J. \& Carstens, E.B. (2012). Ratifikatsiia holosovaniia po taksonomicheskim predlozheniiam v Mezhdunarodnyi komitet po taksonomii virusov [Ratification of voting on taxonomic proposals to the International Committee on Taxonomy of Viruses]. Arkhiv virusolohii - Virology Archive, 157(7), 1411-1422 [in Russian].

15 Papillomavirusy cheloveka [Human papillomaviruses]. wikipedia.org.ru Retrieved from https://ru.wikipedia.org/wiki/ Papillomavirusy cheloveka [in Russian].

16 Sklut, R. (2012). Bessmertnaia zhizn Henrietty Laks [Immortal Life of Henrietta Lax]. Moscow: Karera-Press [in Russian].

17 Paevsky, A. (2015) Uvidevshii virusy v rake. Kharald Tsur Khauzen [Seeing viruses in cancer. Harald zur Hauzen]. biomolecula.ru Retrieved from https://biomolecula.ru/articles/uvidevshii-virusy-v-rake-kharald-tsur-khauzen [in Russian].

18 Paevsky, A. (2018). Nobelevskie laureaty: Harald Tsur Hauzen. Chelovek, soedinivshii virusy i rak [Nobel laureates: Harald zur Hausen. Man connecting viruses and cancer]. indicator.ru Retrieved from https://indicator.ru/medicine/harald-cur-hauzen.htm [in Russian].

19 Polyanichenko, A.A. (2015). Stroenie i klassifikatsiia virusov papillomy cheloveka (literaturnyi obzor) [Structure and classification of human papilloma viruses (literature review)]. Perspektivy razvitiia sovremennoi meditsiny - Prospects for the development of modern medicine (pp. 206). Voronezh [in Russian].

20 Prilepskaya, V.N. (1997). Zabolevaniia sheiki matki: Klinicheskie lektsii [Cervical Diseases: Clinical Lectures]. Moscow: Media-Sfera [in Russian].

21 Prilepskaya, V.N. (1998). Vozrastnye osobennosti sheiki matki. Sovremennye metody diahnostiki patolohii sheiki matki [Age features of the cervix. Modern methods for diagnosing cervical pathology]. Akusherstvo $i$ hinekolohiia - Obstetrics and Gynecology, 6, 51-54 [in Russian].

22 Rusakevich, P.S. (2000). Zabolevaniia sheiki matki: simptomatika, diahnostika, lechenie, profilaktika [Cervical Diseases: Symptoms, Diagnosis, Treatment, Prevention]. Minsk: Vysshaia shkola [in Russian].

23 Khmel'nitskii, O.K. (1999). Tsitolohicheskaia i histolohicheskaia diahnostika zabolevanii sheiki i tela matki [Cytological and histological diagnosis of diseases of the cervix and uterus]. Saint Petersburg: SOTIS [in Russian].

24 Skrining raka sheiki matki v razvivaiushchikhsia stranakh. Doklad o konsultatsii VOZ [Cervical cancer screening in developing countries. WHO consultation report]. who.int.ru Retrieved from https://www.who.int/ru/ [in Russian].

25 Poghosyan, G.P., Protas, V.V., Konovalova, A.A. \& Lee, K.G. (2014). Opredelenie henotipov virusa papillomy cheloveka [Determination of human papillomavirus genotypes]. Proceedings from Molecular diagnostics - 2014: VIII Vserossiiskaia nauchnoprakticheskaia konferentsiia s mezhdunarodnym uchastiem - All-Russian Scientific and Practical Conference with International Participation (pp. 185-186). Moscow: Interlabservis [in Russian].

26 Poghosyan, G.P., Lee, K.G. \& Zhumina, A.G. (2007). Amplifikatsiia DNK nekotorykh virusnykh ahentov [Amplification of DNA of some viral agents]. II Mezhdunarodnaia nauchno-prakticheskaia konferentsiia molodykh uchenykh - II International Scientific and Practical Conference of Young Scientists (pp. 130-135). Taraz [in Russian]. 
27 Munoz, N., Bosch, F.X., \& de Sanjose S. et al. (2003). Epidemiologic classification of human papillomavirus types associated with cervical cancer. New England Journal of Medicine, 348(6), 518-527.

28 Syrjanen, K. \& Syijanen, S. (1990). Epidemiology of human papillomavirus infection and genital neoplasia. The Scandinavian Journal of Infectious Diseases, 69, 7-17.

29 Stefanov, Yu. (2013). Virus papillomy cheloveka [Human papillomavirus]. visual-science.com/ru Retrived from https://visual-science.com/ru/projects/human-papillomavirus/illustration [in Russian].

30 Popov, B.V. (2010). Vvedenie v kletochnuiu biolohiiu stvolovykh kletok [An Introduction to Stem Cell Biology]. Saint Petersburg: SpetsLit [in Russian].

31 Klag, S.W., Cummings M.R., \& Spencer, Ch.A. (2017). Osnovy henetiki [The basics of genetics]. Moscow: Tekhnosfera [in Russian].

32 Krebs, J., Goldstein, E., \& Kilpatrick, S. (2018). Heny po Lyuinu [Lewin genes]. Moscow: Laboratoriia znanii [in Russian].

33 Zur Hausen, H. (1996). Papillomavirus infections are the main cause of human cancer. Biochimica et Biophysica Acta (BBA), 1288(2), 55-78.

34 Alberts, B., Bray, D., Hopkin, K., Johnson, A., Lewis, J., \& Raff, M., et al. (2015). Osnovy molekuliarnoi biolohii kletki [Essential cell biology]. Moscow: Binom. Laboratoriia znanii [in Russian].

35 Pogosyan, G.P., Konovalova, A.A., \& Protas, V.V. (2014). Opredelenie DNK nekotorykh virusov metodom polimeraznoi tsepnoi reaktsii [Determination of DNA of some viruses by polymerase chain reaction]. Proceedings from Modern botany: biodiversity, bioresources, biotechnologies'14: Mezhdunarodnaia nauchno-prakticheskaia konferentsiia - International Scientific and Practical Conference (pp. 319-323). Karaganda: KarSU Publ. [in Russian].

36 Jeon, S. \& Lambert, P.F. (1995). Integration of human papillomavirus type 16 DNA into the human genome leads to increased stability of E6 and E7 mRNAs: implications for cervical carcinogenesis. Proceedings of the National Academy of Science USA, 92, 1654-1658.

37 Bechtold, V., Beard, P., \& Raj, K. (2003). Human papillomavirus type 16 E2 protein has no effect on transcription from episomal viral DNA. The Journal of Virology, 77, 2021-2028.

38 Tan, S.H., Leong, L.E., Walker, P.A., \& Bernard, H.U. (1994). The human papillomavirus type $16 \mathrm{E}_{2}$ transcription factor binds with low cooperativity to two flanking sites and represses the $\mathrm{E}_{6}$ promoter through displacement of Spl and TFIID. The Journal of Virology, 68, 6411-6420.

39 Daniel, B., Rangarajan, A., \& Mukheijee, G. et al. (1997). The link between integration and expression of human papillomavirus type 16 genomes and cellular changes in the evolution of cervical intraepithelial neoplastic lesions. The Journal of General Virology, 78, 1095-1101.

40 Stunkel, W. (2000). Nuclear matrix attachment regions of human papillomavirus type 16 repress or activate the $\mathrm{E}_{6}$ promoter, depending on the physical state of the viral DNA. The Journal of Virology, 74, 2489-2501.

41 Romanczuk, H., \& Howley, P.M. (1992). Disruption of either the E1 or the E2 regulatory gene of human papillomavirus type 16 increases viral immortalization capacity. Proceedings of the National Academy of Science USA, 89, 3159-3163.

42 Hou, S.Y., Wu, S.Y., \& Chiang, C.M. (2002). Transcriptional activity among high and low risk human papillomavirus $\mathrm{E}_{2}$ protein correlates with $E_{2}$ DNA binding. The Journal of Biological Chemistry, 277, 45619-45629.

43 Ueda, Y., Enomoto, T., \& Miyatake, T. et al. (2003). Monoclonal expansion with integration of high-risk type human papillomaviruses is an initial step for cervical carcinogenesis: association of clonal status and human papillomavirus infection with clinical outcome in cervical intraepithelial neoplasia. Laboratory Investigation (journal), 83, 1517-1527.

44 Thorland, E.C., Myers, S.L., Gostout, B.S., \& Smith, D.I. (2003). Common fragile sites are preferential targets for HPV16 integrations in cervical tumors. Oncogene (journal), 22, 1225-3127.

45 Mullokandov, M.R., Kholodilov, N.G., Atkin, N.B. et al. (1996). Genomic alterations in cervical carcinoma: losses of chromosome heterozygosity and human papilloma virus tumor status. Cancer Research, 56, 197-202.

46 Goldie, S.J., Wu, F., \& Asplund, A. et al. (2001). Analysis of intratumoral heterogeneity of chromosome $3 p$ deletions and genetic evidence of polyclonal origin of cervical squamous carcinoma. Modern Pathology, 14, 54-61.

47 Zur Hausen, H. (2002). Papillomaviruses and cancer: from basic studies to clinical application. Nature Reviews Cancer, 2 , $342-350$.

48 Mazurenko, N., Attaleb, M., \& Gritsko, T. et al. (1999). High resolution mapping of chromosome 6 deletions in cervical cancer. Oncology Reports, 6, 859-863.

49 Koopman, L.A., Corver, W.E., \& Van Der Slik, A.R. et al. (2000). Multiple genetic alterations cause frequent and heterogeneous human histocompatibility leukocyte antigen class I loss in cervical cancer. Journal of Experimental Medicine, 191, 961-975. 